\title{
Human Capital Investment and Economic \\ Competitiveness (Indonesian Competitiveness among ASEAN Countries)
}

\author{
Saparso \\ Faculty of Economics and Business, Krida Wacana Christian University, Indonesia \\ E-mail: saparso@ukrida.ac.id
}

Hery Winoto

Faculty of Economics and Business, Krida Wacana Christian University, Indonesia

E-mail: hery.winoto@ukrida.ac.id

Soegeng Wahyoedi (Corresponding author)

Faculty of Economics and Business, Krida Wacana Christian University, Indonesia

E-mail: swahyoedi@ukrida.ac.id

Received: June 7, 2019 Accepted: June 21, 2019 Published: July 5, 2019

doi:10.5296/ber.v9i3.15028ＵRL: https://doi.org/10.5296/ber.v9i3.15028

\begin{abstract}
The objective of this paper is to investigate empirically the effects of investment in human capital on the competitiveness of the nation. Investment in human capital, particularly in terms of education, health, research and development, stimulates the economic growth and competitiveness of a country. The innovations developed through research and development ( $\mathrm{R}$ and $\mathrm{D}$ ) have been believed to cause the rapid economic growth. Education will also contribute to science and knowledge through $\mathrm{R}$ and $\mathrm{D}$ which is highly required for economic growth. Using descriptive cross-section data of investment in human capital combined with neoclassical economic thought, the paper investigates the transmission mechanisms of human capital investment to economic competitiveness of nations. The result of this research shows that the increasing growth of investment in human capital is positively correlated with the increase in the competitiveness of a country.
\end{abstract}




\section{Macrothink}

Key words: Human capital investment, Competitiveness of the nations, Education, Health, Research and development

\section{Introduction}

World Economic Forum has recently published the global competitiveness report 2017/2018. The report shows that the top 10 countries with high rate of competitiveness have not experienced a significant change compared to the previous years, wherein Switzerland is the country with the world's highest competitiveness in 2017/2018. Competitiveness is a key for a country to compete in a competition. As the competition is increasing among countries, industries, as well as companies, the only keyword to win the competition is by improving the rate of competitiveness.

Competitiveness becomes a strategic factor as it is related to a country's prosperity measured by income per capita of a country. The higher the competitiveness of a country, the higher its level of prosperity reflected through the high amount of income per capita of the country's inhabitants. Subsequently, should a country aim to prosper its inhabitants, the primary keyword would be to increase its economic competitiveness.

Dong Sung Cho and Hwy-Chang Moon (2000 and 2013) have proposed a comprehensive synthesis regarding the competitiveness. They synthesized scholars' thoughts on competitiveness starting from Adam Smith to Michael Porter. Further, the summary of arguments on competitiveness reveals that there is a paradigm shift in competitiveness based on resource superiority which happens to be a gift, i.e. an abundant availability of resources referring to superiority-based competitiveness created through superiority in quality of resources, specifically human capital resources. This can be examined through observation which highlights that countries holding high ranks in global competitiveness in Global Competitiveness Report own superior human capital resources as well.

Human Capital Report states "A nation's human capital endowment - the knowledge and skills embodied in individuals that enable them to create economic value - can be a more important determinant of its long-term success than virtually any other resources" (Human Capital Report 2016:8). Consequently, it can be inferred that the primary elements of human capital are education, health, and research and development. These three primary elements will increase the quality of human resources which in turn will increase a country's competitiveness.

\section{Research Problems}

1. Does education owned by a country affect its competitiveness?

2. Does health affect a country's competitiveness?

3. Does research and development affect a country's competitiveness?

\section{Literature Review and Hypotheses}

Schwab (2016:4) defines Competitiveness as follows: "we define competitiveness as the set of institutions, policies, and factors that determine the level of productivity of an economy, 
which in turn, sets the level of prosperity that the country can earn". In reference to the above definition, competitiveness can be defined as a high growth of economy which is able to prosper the citizens of a country. This high economic growth is achieved by synergizing factors which encourage productivity.

In addition, Djurica, Djurica, and Janivcic (2014) argue that knowledge, skills, creativity, innovativeness, ability to learn, and other valuable features which people own have become key elements in modern economy, both for their earning capacity and competitiveness and other economic performances of a company. The terms of 'IT society', 'Learning society', 'Network economy', 'New economics', 'Knowledge-based economy', 'Knowledge economy', 'Innovative economy' have been used to describe the growing importance of intellectual capital on competitiveness of a company and economic and social development of a country.

There are at least two institutions which are significantly active in measuring countries' competitiveness, i.e. World Economic Forum and IMD World Competitiveness Centre. World Economic Forum (WEF) routinely launches "Global Competitiveness Report" as a means to highlight the performance of a country's competitiveness. WEF defines national competitiveness as a national economic capability to achieve high and sustainable economic growth. The focus is placed on the appropriate policies, suitable institutions, and other economic characteristics supporting the realization of high and sustainable economic growth.

Meanwhile, Institute of Management Development (IMD) has published the "World Competitiveness Yearbook". In a definition proposed by IMD, competitiveness is a form of capability of a country in creating extra value in increasing national wealth by managing assets and process, attractiveness and aggresivity, globality and proximity, as well as by integrating the respective relations into an economic and social model.

IMD classifies the determining factors of competitiveness into four categories, i.e.

1. Economic performance

- Domestic economy

- International trade

- International investment

- Employment

- Prices

2. Government efficiency:

- Public Finance

- Fiscal policy

- Institutional framework

- Business legislation 
- Societal framework

3. Business efficiency:

- Productivity and efficiency

- Labor market

- Finance

- Management practices

- Attitudes and values

4. Infrastructure:

- Basic infrastructure

- Technological infrastructure

- Scientific infrastructure

- Health and environment

- Education

Out of the two institutions measuring the competitiveness, it can be examined that human capital factor, in forms of education, health and innovation, is a significant factor which determines a country's competitiveness.

Dong Sung Cho and Hwy-Chang Moon (2000 and 2013) have proposed a comprehensive synthesis regarding the competitiveness. They synthesized scholars' thoughts on competitiveness starting from Adam Smith to Michael Porter. Further, the summary of arguments on competitiveness reveals that there is a paradigm shift in competitiveness based on resource superiority which happens to be a gift, i.e. an abundant availability of resources referring to superiority-based competitiveness created through superiority in quality of resources, specifically human capital resources. This can be examined through an observation which highlights that countries holding high ranks in global competitiveness in Global Competitiveness Report also have superior human capital resources.

A superior human capital is the main key to determine the competitiveness. Sollow (1956) defines that the growth of technology enables an increase in productivity, and in turn, an increase in economic growth (competitiveness) as well. The element of technology as a determinant of growth factor has resulted a significant revolution in a theory of economic growth. Sollow describes his theory in reference to Sollow's productive function, i.e.

$$
\mathrm{Y}=\mathrm{K}^{\alpha} \mathrm{A} \mathrm{L}^{1-\alpha}
$$

in which $\mathrm{Y}$ is an output (product and service), $\mathrm{K}$ is a physical capital (machine), and $\mathrm{L}$ is labor, $\alpha$ is a coefficient, and $\mathrm{A}$ is technology. In an assumption of its constant return to scale, the growth of $(\mathrm{K})$ and $(\mathrm{L})$ will work in line with the growth of the output. This indicates that 
if $(\mathrm{K})$ and $(\mathrm{L})$ are doubled in number, the output will be doubled as well.

A linear relation between technology and output is then explained by Roomer (1996), who assembles thoughts proposed by Roomer (1990), Grossman and Helpman (1991), and Aghion and Howitt (1992) who elaborate the technological factor as the trigger of economic growth, which later is named as The New Growth Theory. The transformation from technology to become an output is facilitated by productivity. Technology creates productivity, and further increases the output.

Productivity is also determined by technology as a part of knowledge composition which is believed by Tapscott (1997) to be one of the forms of the New Economy. One of the characteristics of new economy is the reliance towards knowledge and science. According to Tapscott (1997), people tend to work harder by using brain instead of muscles. An annual study conducted by World Bank in 1998/1999 has also raised knowledge as its topic of discussion and entitled Knowledge for Development as the world development annual report in 1998/1999. In reference to the study proposed by World Bank (1998/1999), it can be inferred that there is a strong and positive correlation between the growth of knowledge and the growth of economy of a country.

Phillipe Aghion and Peter Howitt (1992:349) state: "Growth results exclusively from technological progress, which in turn from competition among research firms that generate innovation. Each innovation consists of new intermediate goods that can be used to produce final output more efficiently than before". Innovations being developed through research and development are believed to cause the fast economic growth. Industrial countries are recorded to spend high cost of R and D. Aghion and Howitt (1992) exemplify that there are various ways to accumulate knowledge, starting from formal education, on the job training, basic scientific research, learning by doing, innovative processes, and product innovations.

Human Capital Report states that "A nation's human capital endowment - the knowledge and skills embodied in individuals that enable them to create economic value - can be a more important determinant of its long-term success than virtually any other resources" (Human Capital Report 2016:8). Consequently, in reference to the above definition, the primary elements of human capital which will determine the long term achievement of a country are knowledge and skills.

The performance of human capital investment is recorded in The Human Development Index (HDI) containing a summary of average achievement in key dimensions of human development, i.e. having a long and healthy life, being knowledgeable, and having a decent standard of living. Consequently, it can be inferred that the primary elements of human capital are education, health, and research and development. These three primary elements will increase the quality of human resources which in turn will increase a country's competitiveness.

This research will investigate the effect of human capital investment on competitiveness of nations. Furthermore, this research aims to reveal the effects of education, health, and research and development on the competitiveness of nations. 


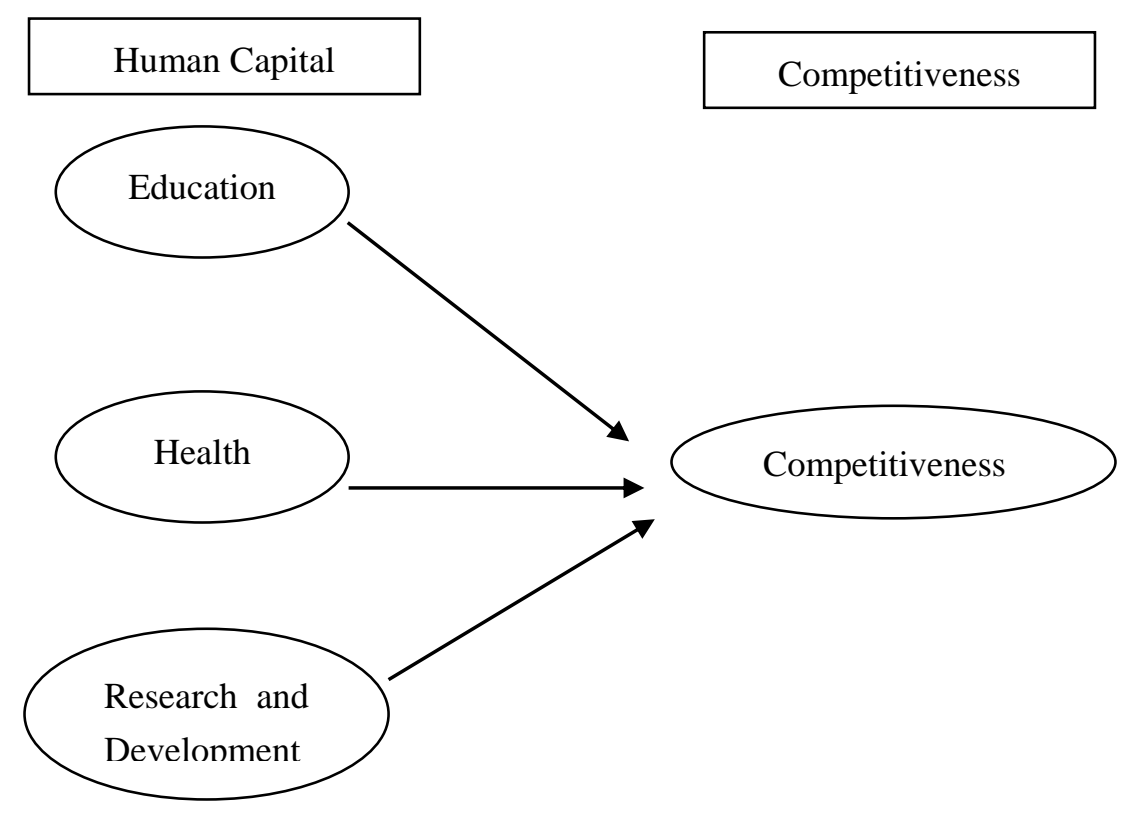

\section{Hypothesis 1}

There is a positive significance relationship between duration of schooling and competitiveness.

\section{Hypothesis 2}

There is a positive significance relationship between government expenditure on public health and competitiveness.

\section{Hypothesis 3}

There is a positive significance relationship between government expenditure on research and development and competitiveness.

\section{Methodology}

Human capital and economic competitiveness of a nation have a strong relationship. Investment on human capital affects economic growth and supports a country to develop its economy through the knowledge and skills of people. The relationship can be examined by measuring the expenditures invested into the sectors of education, health, and research and development. For instance, a number of countries offer higher education to the citizens at no cost. These countries realize that the knowledge which people gain through education will eventually contribute to the economic development and further lead to the economic growth.

\section{Sample}

The data of this research were cross sectional data collected from a population of 137 countries in Global Competitiveness Report in 2017/2018 published by World Economic Forum, along with the data of 188 countries taken from Human Development Index published by World Bank. From the above population, 115 countries with complete data on 


\section{Macrothink}

education, health, and research and development were examined to test the effects on competitiveness.

\section{Measures}

WEF classifies the determining elements of competitiveness index into three main sub indexes, i.e. Basic Requirements Sub index, Efficiency Enhancers Sub index, and Innovation and Sophistication Sub index. These three respective factors are crystalized out of these following twelve foundations (WDR, 2017/2018):

Basic Requirements Sub index

1. Institutions

2. Infrastructure

3. Macroeconomic environment

4. Health and primary education

Efficiency Enhancers Sub index

5. Higher education and training

6. Good market efficiency

7. Labor market efficiency

8. Financial market development

9. Technological readiness

10. Market size

Innovation and sophistication factors sub index

\section{Business sophistication}

12. Innovation

The health dimension is assessed by government expenditure in health sector in a form of percentage out of the total of government expenditure. Thus, the education sector is measured by the duration of schooling for adults, while the sector of research and development is measured by the country's expenditure spend on research and development as a percentage of gross domestic product. These following data were all obtained from the data provided by World Bank. In addition, the level of competitiveness is measured through the score data of a country's competitiveness obtained from Global Competitiveness Report 2017/2018 published by World Economic Forum.

\section{Model Specification}

The effects of human capital investment (Education, Health and Research and Development) on the competitiveness are formulated as follows: 


$$
Y=\beta o+\beta_{1} X_{1}+\beta_{2} X_{2}+\beta_{3} X_{3}
$$

As a dependent variable, $\mathrm{Y}$ is a country's competitiveness

While the independent variables are:

$\mathrm{X}_{1}$ - education

$\mathrm{X}_{2}-$ health

$\mathrm{X}_{3}$ - research and development $(\mathrm{R}$ and $\mathrm{D})$

$\beta$ o intercept

$\beta_{1}-\beta_{3}$ regression coefficient

\section{Result and Discussion}

The Relationship between Human Capital Investment (education, health, and research and development) and Competitiveness.

The relationship between education, health, and research and development and competitiveness can be observed in the following table 1. The relationship between Education and Competitiveness is as much as $r=0.724$ statistically significant at $1 \%$ level (p value $=0.00)$, indicating an adequately strong and positive relationship. This indicates that the longer duration of education a labor undergoes will increase the country's competitiveness. The longer a labor in a country undergoes education, the more knowledge and skill they obtain enabling them to be more productive, which in the end, leading to an increase in the competitiveness.

Moreover, the relationship between health and competitiveness is shown by the correlation value of $\mathrm{r}=0,556$ statistically significant at $1 \%$ level ( $\mathrm{p}$ value $=0.00$ ), indicating an adequately strong and positive relationship. The finding indicates that the healthier a labor is, the better the person will be able to perform, and in the end, it increases the level of competitiveness.

The relationship between research and development and competitiveness is $r=0,647$ statistically significant at $1 \%$ level $(\mathrm{p}$ value $=0.00$ ). This value shows a strong and positive relationship. This indicates that the higher expenditure on research and development signifies capability in creating new innovations and granting uniqueness which further will increase the country's competitiveness.

Table 1. Relationship between education, health, and research and development and competitiveness

\begin{tabular}{|l|l|l|l|l|l|}
\hline \multicolumn{2}{|c|}{} & Competitiveness & Health & RandD & Education \\
\hline Pearson Correlation & Competitiveness & 1,000 &, 556 &, 647 &, 724 \\
\cline { 2 - 6 } & Health &, 556 & 1,000 &, 568 &, 517 \\
\cline { 2 - 6 } & R and D &, 647 &, 568 & 1,000 &, 530 \\
\cline { 2 - 6 } & Education &, 724 &, 517 &, 530 & 1,000 \\
\hline
\end{tabular}




\begin{tabular}{|l|l|l|l|l|l|}
\hline \multirow{4}{*}{ Sig. (1-tailed) } & Competitiveness &. &, 000 &, 000 &, 000 \\
\cline { 2 - 6 } & Health &, 000 &. &, 000 &, 000 \\
\cline { 2 - 6 } & R and D &, 000 &, 000 &. &, 000 \\
\cline { 2 - 6 } & Education &, 000 &, 000 &, 000 &. \\
\hline \multirow{4}{*}{$\mathrm{N}$} & Competitiveness & 115 & 115 & 115 & 115 \\
\cline { 2 - 6 } & Health & 115 & 115 & 115 & 115 \\
\cline { 2 - 6 } & R and D & 115 & 115 & 115 & 115 \\
\cline { 2 - 6 } & Education & 115 & 115 & 115 & 115 \\
\hline
\end{tabular}

The effect of education, health, and expenditure on research and development can be examined in this following table.

Table 2. The effect of education, health, and research and development on competitiveness

\begin{tabular}{|c|c|c|c|c|c|c|}
\hline \multirow{2}{*}{\multicolumn{2}{|c|}{ Model }} & \multicolumn{2}{|c|}{ Unstandardized Coefficients } & \multirow{2}{*}{$\begin{array}{l}\text { Standardized Coefficients } \\
\text { Beta }\end{array}$} & \multirow[t]{2}{*}{$\mathrm{t}$} & \multirow[t]{2}{*}{ Sig. } \\
\hline & & B & Std. Error & & & \\
\hline \multirow[t]{4}{*}{1} & (Constant) & 2,968 & 134 & & 22,091 & ,000 \\
\hline & Health & ,035 & ,022 & ,122 & 2,058 &, 042 \\
\hline & $\mathrm{R}$ and $\mathrm{D}$ & ,215 &, 051 &, 316 & 4,237 &, 000 \\
\hline & Education & ,113 & ,016 & 494 & 6,882 & ,000 \\
\hline
\end{tabular}

a. Dependent Variable: Competitiveness

$\mathrm{Y}=2.968+0.113 \mathrm{X} 1+0.035 \mathrm{X} 2+0,215 \mathrm{X} 3$

t value $\quad(22,091) \quad(6,882) \quad(2,058) \quad(4,237)$

The equation has an adequately high $\mathrm{R}^{2}$ (coefficient of determination) as much as 0,629 significant at the $1 \%$ level ( $\mathrm{p}$ value $=0.00 \%$ ). Subsequently, it can be inferred that an increase in human capital (education, health, research and development) investment will also increase the level of competitiveness.

\section{Hypothesis 1}

The effect of education on competitiveness

The effect of education on competitiveness is as much as 0.113 statistically significant at the $1 \%$ level ( $\mathrm{p}$ value $=0.00$ ). This indicates that the duration of one's education will increase the country's competitiveness. This notion is in line with the findings proposed by Baumann and Winzar (2016) who have managed to analyze the data of Programme for International Student Assessment (PISA) from 63 countries to ascertain the role of education in explaining the competitiveness of a country. They reveal that education indeed contributes to improve the competitiveness. The strength of East Asia in educational achievement will have implications on the region's future competitiveness compared to Anglo-Saxon and European countries. 
These empirical findings support the theoretical arguments for education's role in driving the competitiveness.

\section{Hypothesis 2}

The effect of health on competitiveness

The effect of government expenditure on health can be measured by referring to the amount of the country's expenditure on health which affects as much as 0.035 statistically significant at the $5 \%$ level ( $\mathrm{p}$ value $=0.042$ ). This indicates that there is an adequate evidence to prove that government expenditure on health sector has a strong effect on competitiveness. This finding supports what is proposed by Reinhardt (1989) in which he states that an increase in health care costs translate themselves directly into higher productivity and drive competitiveness.

\section{Hypothesis 3}

The effect of research and development on competitiveness

The government expenditure on $\mathrm{R}$ and $\mathrm{D}$ sector has an effect on the competitiveness as much as 0.215 statistically significant at $1 \%$ level $(\mathrm{p}$ value $=0.00$ ). This finding strengthens the argument highlighting that the higher amount of expenditure allocated by a country on research and development, the higher the competitiveness will be. Over the first decade of the twenty-first century, the total public and private R and D expenditures in U.S grew at merely 5 percent a year, reaching $\$ 400$ billion annually in 2009. Meanwhile, $\mathrm{R}$ and D spending has generally surged across Asia, with China and South Korea maintaining double digit growth rates. China became the second highest spender on $\mathrm{R}$ and $\mathrm{D}$ worldwide, with $\$ 154$ billion in 2009, surpassing Japan. In the same period, the European Union averaged 5.8 percent of R and D growth, reaching $\$ 300$ billion (Markovich, 2012).

In reference to the table 2, it can be examined that research and development is a dominant variable determining the competitiveness followed by education and health. This indicates that the government of a country should put serious attention to the expenditures on research and development. Research and development ( $R$ and $D)$ is the backbone of a globally competitive and knowledge-driven economy. $\mathrm{R}$ and $\mathrm{D}$ investment helps develop new products and services that drive growth, create jobs, and improve the national welfare. High expenditure on research and development will increase the capabilities in creating new innovation in knowledge creation which is believed by New Growth Theory adherents as an Engine of Growth.

The Implications for Indonesia's Competitiveness among ASEAN Countries

The Association of Southeast Asian Nations (ASEAN) was established on 8 August 1967. The members of ASEAN are Brunei Darusssalam, Cambodia, Indonesia, Lao PDR, Malaysia, Myanmar, Phillipines, Singapore, Thailand, and Vietnam. Furthermore, by the end of 2015, ASEAN has entered the era of ASEAN Economic Community creating:

1. a single market and production base, 
2. a highly competitive economic region,

3. a region of equitable economic development,

4. a region fully-integrated into the global economy

By 2015, the ASEAN Economic Community (AEC), envisioned as a single common market and production base, has become a reality. This leads to the freer flow of goods, services, investment capital, and skilled labor in the region. Tariff and non-tariff barriers will be reduced, which will have implications for intraregional trade and investment. New opportunities for growth and prosperity are likely to emerge, but the challenge is to ensure that growth is inclusive and prosperity is shared. Ultimately, the success of ASEAN regional integration will depend on how it affects the labor market; and therefore, how it improves the quality of life in the region.

Citing the opinion proposed by Aring (2015), the goal of the ASEAN Economic Community is to improve the material welfare and well-being of member states through the establishment of ASEAN as a single market and production base. Realisation of this goal requires the elimination of barriers to the flow of goods, services, investments and skilled labor within the region, be they at-the-border or beyond-the-border barriers. At the same time, the region aims at being globally competitive.

ASEAN is an adequately huge and attractive market. The population of ASEAN reaches more than 655 million people with income per capita ranging between US\$1,263US\$ 57,173 (IMF, 2018), while the trading transaction reaching up to US\$ 600 billions, making ASEAN as the promising joint market. Nevertheless, AEC creates a competition among ASEAN countries, with a success indicator to win the competition is through human capital competitiveness. The country which highlights the importance of competitiveness is Indonesia. This is due to the amount of Indonesian inhabitants reaching up to 251.5 million, i.e. almost half of the entire ASEAN inhabitants. If Indonesia is incapable of increasing its competitiveness, Indonesian market will be dominated by other ASEAN countries.

The position of Indonesia within ASEAN countries can be seen in Table 3 as follows:

Table 3. The Position of Competitiveness and Human Capital in ASEAN Countries

\begin{tabular}{|l|l|l|l|l|l|}
\hline \multirow{2}{*}{ Country } & \multirow{2}{*}{$\begin{array}{l}\text { Income per } \\
\text { capita (US\$) }\end{array}$} & \multicolumn{2}{l|}{$\begin{array}{l}\text { Competitiveness } \\
\text { Rank (2017/18) }\end{array}$} & \multicolumn{2}{l|}{$\begin{array}{l}\text { Human Capital } \\
\text { Rank (2017) }\end{array}$} \\
\cline { 3 - 6 } & & Global & ASEAN & Global & ASEAN \\
\hline Singapore & 57,713 & 3 & 1 & 11 & 1 \\
\hline Malaysia & 9,812 & 23 & 2 & 33 & 2 \\
\hline Thailand & 6,590 & 32 & 3 & 40 & 3 \\
\hline Indonesia & 3,875 & 36 & 4 & 65 & 7 \\
\hline Brunei Darussalam & 29,711 & 46 & 5 & 58 & 5 \\
\hline Vietnam & 2,353 & 55 & 6 & 64 & 6 \\
\hline Philippines & 2,976 & 56 & 7 & 50 & 4 \\
\hline Cambodia & 1,389 & 94 & 8 & 92 & 10 \\
\hline
\end{tabular}




\begin{tabular}{|l|l|l|l|l|l|}
\hline Lao PD & 2,542 & 98 & 9 & 84 & 8 \\
\hline Myanmar & 1,263 & $112^{*)}$ & 10 & 89 & 9 \\
\hline
\end{tabular}

Source: *) World Development Report 2015/2016

IMF, World Economic Outlook Database, 2018

WEF, Global Human Capital Report, 2017

Out of 137 countries in Global Competitiveness Report in 2017/2018, Singapore is placed third in the world's competitiveness, while in ASEAN, Singapore reaches the first place. Meanwhile, Singapore's human capital is placed in rank 11 in the world, and rank $1^{\text {st }}$ in ASEAN. Indonesia, as the country with the highest population, is placed in rank 36 in the world in terms of global competitiveness, and is ranked $4^{\text {th }}$ in ASEAN, while in terms of human capital, Indonesia holds rank 65 in the world, and $7^{\text {th }}$ in ASEAN.

Singapore reaches the first place in the human capital rank for ASEAN countries, followed by Malaysia and Thailand. Meanwhile, Indonesia is in the $7^{\text {th }}$ position following Lao PD and Myanmar. This indicates that Indonesia is still far left behind in regards of human capital investment.

The position of educational factor in Indonesia measured from the length of school year to be completed compared to other ASEAN countries can be seen in table 4 below.

Table 4. Mean years of schooling

\begin{tabular}{|l|l|l|}
\hline Country & Year & ASEAN Rank \\
\hline Singapore & 11.6 & 1 \\
\hline Malaysia & 10.1 & 2 \\
\hline Thailand & 7.9 & 6 \\
\hline Indonesia & 7.9 & 7 \\
\hline Brunei Darussalam & 9.0 & 4 \\
\hline Vietnam & 8.0 & 5 \\
\hline Philippines & 9.3 & 3 \\
\hline Cambodia & 4.7 & 9 \\
\hline Lao PD & 5.2 & 8 \\
\hline Myanmar & 4.7 & 10 \\
\hline
\end{tabular}

Source: World Bank, HDI Rank, 2015

Referring to Table 4, Indonesia is at the $7^{\text {th }}$ rank out of 10 ASEAN countries. This describes that the educational level of Indonesian human capital is far behind other ASEAN countries. The educational field which is left behind becomes one of the factors causing the low productivity of Indonesian labors and lowering competitiveness. 


\section{Macrothink}

Business and Economic Research

ISSN 2162-4860

2019, Vol. 9, No. 3

Moreover, the low rate of human capital in Indonesia is also referred to the position of government expenditure on health. Health is one of the factors of human capital determining a country's competitiveness. The comparison of government expenditure in the health sector can be examined in the following table.

Table 5. Health Expenditure as a Percentage of GDP

\begin{tabular}{|l|l|l|}
\hline Country & \% GDP & ASEAN Rank \\
\hline Singapore & 2.1 & 5 \\
\hline Malaysia & 2.3 & 4 \\
\hline Thailand & 5.6 & 1 \\
\hline Indonesia & 1.1 & 8 \\
\hline Brunei Darussalam & 2.5 & 3 \\
\hline Vietnam & 3.8 & 2 \\
\hline Philippines & 1.6 & 6 \\
\hline Cambodia & 1.3 & 7 \\
\hline Lao PD & 0.9 & 10 \\
\hline Myanmar & 1 & 9 \\
\hline
\end{tabular}

Source: World Bank, HDI Rank, 2015

In reference to table 5, health expenditure as a percentage of total gross domestic product in Indonesia is still far behind other ASEAN countries, and is only ahead of Myanmar and Lao PD.

Meanwhile, the research and development as a dominant variable in determining competitiveness among ASEAN countries can be seen in table 6 as follows.

Table 6. Research and Development Expenditure as a Percentage of GDP

\begin{tabular}{|l|l|l|}
\hline Country & \% GDP & ASEAN Rank \\
\hline Singapore & 2.19 & 1 \\
\hline Malaysia & 0.16 & 4 \\
\hline Thailand & 0.62 & 2 \\
\hline Indonesia & 0.08 & 8 \\
\hline Brunei Darussalam & 0.03 & 9 \\
\hline Vietnam & 0.30 & 3 \\
\hline Philippines & 0.13 & 6 \\
\hline Cambodia & 0.11 & 7 \\
\hline Lao PD & 0.03 & 10 \\
\hline Myanmar & 0.16 & 5 \\
\hline
\end{tabular}

Source: World Bank, HDI Rank, 2015 
In reference to Table 6, Indonesia is left behind compared to other ASEAN countries. Singapore still holds the leading role in research and development expenditure as a percentage of GDP. Indonesia's position in the fields of education, health, and research and development, which is considered to be low, causes Indonesia's competitiveness in the scope of ASEAN is also low. The low rate of human capital in Indonesia also causes Indonesia to be flooded by products and services from ASEAN countries as it is regulated in AEC that products and services will be traded freely from one country to another in the region of ASEAN.

\section{Conclusion}

Human capital has a positive effect on global competitiveness of a country. The more a country spends its investment on human capital, the more chances the global competitiveness of the country increases. Therefore, the investment on human capital is necessary to increase the competitiveness of a country.

Education, health, and research and development have effects on country's global competitiveness. It means that a country should pay serious attention on expenditure of research and development because the increase in expenditure of research and development will create impact in increasing global competetiveness of a country.

The low rate of Indonesia's competitiveness is primarily caused by the low rate of Human Capital owned by Indonesia. Consequently, should Indonesia aim to hold a dominant role in AEC, the education, health, and research and development should also gain serious attention from Indonesian government to be improved.

\section{References}

Aghion, P., \& Howit, P. (Eds.), (1992). A Model of Growth Through Creative Destruction. Econometrica, 60(2), 323-351. https://doi.org/10.2307/2951599

Aring, M. (2015). ASEAN Economic Community 2015: enhancing competitiveness and employability through skill development, ILO Regional Office for Asia and the Pacific, Bangkok.

ASEAN Economic Blue Print, 2012

Barro, R. J. (1993). Macroeconomics, 4th ed., John Wiley and Son, New York.

Bauman, C., \& Winzar, H. (2016). The Role of Secondary Education in Explaining Competitiveness. Asia Pacific Journal, 36(1). https://doi.org/10.1080/02188791.2014.924387

Dong-Sung, C., \& Hwy-Chang, M. (2000). From Adam Smith to Michael Porter: Evolution of Competitiveness Theory. World Science, Singapore.

Dong-Sung, C., \& Hwy-Chang, M. (2013). From Adam Smith to Michael Porter: Evolution of Competitiveness Theory Extended Edition. World Science, Singapore.

Djurica, M., Djurica, N., \& Janicic, R. (2014). Building Competitive Advantage Through Human Capital. The Clute Institute International Academic Conference, Munich. 


\section{IIMacrothink}

Business and Economic Research

ISSN 2162-4860 2019, Vol. 9, No. 3

Grossman, G., \& Helpman, E. (1991). Innovation and Growth in the Global Economy. MIT Press, Cambridge MA.

Klaus, S. (2015). Global Competitiveness Report. World Economic Forum 2015., Geneva

Markovich, S. J. (2012). Promotion Innovation Through R and D., Council on Foreign Relation.

Roomer, D. (1996). Advanced Macroeconomics, McGraw Hill, Singapore, (especially chapter 3).

Sollow, R. M. (1956). A Contribution to the Theory of Economic Growth. The Quarterly Journal of Economics, 70(1), 65-94. https://doi.org/10.2307/1884513

Grossman, G., \& Helpman, E. (1991). Innovation and Growth in the Global Economy. MIT Press, Cambridge MA.

Tapscott, D. (1997). Strategy in the New Economy, Strategy and Leadership, 25(6), 8-14. https://doi.org/10.1108/eb054601

World Development Report 2018

World Development Indicator 2017

Global Competitive Report 2017/2018

Global Human Capital Index 2017

International Monetary Fund World Economic Outlook Data Base, April 2018

\section{Copyright Disclaimer}

Copyright for this article is retained by the author(s), with first publication rights granted to the journal.

This is an open-access article distributed under the terms and conditions of the Creative Commons Attribution license (http://creativecommons.org/licenses/by/3.0/). 